\title{
On the Distribution of "Calcium"* in Tokyo Bay
}

\author{
By
}

\section{Yoshihiro Matida}

In the previous paper ${ }^{1)}$ on the chemical composition of sea water in Tokyo Bay, it was reported that only the alkalinity showed a considerable fluctuation and a difference between water samples collected respectively at outer and inner parts of Tokyo Bay. As it is generally that there is a close correlation between alkalinity and the amount of calcium.2) The present author studied this correlation in this work. In the previous study the gravimetric method by T. G. Thompson ${ }^{3}$ ) was adopted in determining the calcium content in sea water, but here the volumetric method was applied. By comparing the data obtained with both methods, D. A. Webb's4) proposal was examined. The reason of the anormaly in the calcium content and its chlorinity ratio were also considered.

Hitherto, regarding the origin of lime stone and marine life's skeletons, many researches have been done. And also, on the oceanographic view point, to determine the chemical composition of the oceanic salt and its distribution in the ocean, or to clarify the correlation between calcium and alkalinity, several investigations have been done.5) The author intend to repeat here the results of his study concerning the distribution of so-called "Calcium" content in Tokyo Bay.

The author desire to acknowledge to Dr. Y. Miyake and Dr. M. Migita for their kindness in criticizing the manuscript.

\section{Water Samples and Analytical Methods.}

Samples.--Water samples from Tokyo Bay were collected by the observation ship, the "Shinshiru Maru", and those of oceanic water by the "Soyo Maru" at point about thirty miles south of "Tanega-shima" Island. Stations and dates of sampling are shown in Table 1 and 2 with results of chemical analysis.

Methods of Chemical Analysis.--(1) “Calcium". T. G. Thompson's method ${ }^{3}$ was used except the final volumetric procedure. "Calcium" oxalate obtained from $50 \mathrm{cc}$. of sample water was reprecipitated thrice, and was filtered through a 3G4 glass filter and was washed with 5\% ammonia solution previously saturated with "Calcium" oxalate which was prepared from sea water in the same way. The precipitate was dissolved with a small quantity of hot water and 18 normal sulfuric acid, and then it was titrated with 0.05 normal potassium permanganate

* "Calcium" is the sum of the calcium and strontium calculated as calcium. 
Table 1.

\begin{tabular}{|c|c|c|c|c|c|c|c|c|c|}
\hline $\begin{array}{c}\text { Station \& } \\
\text { Date }\end{array}$ & $\begin{array}{c}\text { Depth } \\
\mathrm{m}\end{array}$ & $\begin{array}{c}\text { Temp. } \\
{ }^{\circ} \mathrm{C}\end{array}$ & $\begin{array}{l}\mathrm{Cl} \\
0 \% 00\end{array}$ & $\begin{array}{c}\mathrm{Ca} \\
\mathrm{mg} / \mathrm{kg}\end{array}$ & $\mathrm{Ca} / \mathrm{Cl}$ & $\begin{array}{c}\mathrm{Mg} \\
\mathrm{mg} / \mathrm{kg}\end{array}$ & $\mathrm{Mg} / \mathrm{Cl}$ & $\begin{array}{r}\mathrm{HCO}_{3} \\
-\mathrm{kg} / \mathrm{kg} \\
\end{array}$ & $\mathrm{HCO}_{3} / \mathrm{Cl}$ \\
\hline N 35.36 & 0 & 13.3 & 16.37 & 353.3 & 0.02158 & & & & \\
\hline $\begin{array}{l}\text { E } 139.53 \\
\text { Nov. } 29 \\
1948\end{array}$ & 5 & 15.50 & 17.61 & 374.2 & 0.02125 & 1,175 & 0.06686 & 0.1404 & 0.007995 \\
\hline \multirow{3}{*}{$\begin{array}{c}\mathrm{N} 35.33 \\
\mathrm{E} 140.00 \\
\text { Nov. } 29 \\
1948\end{array}$} & 0 & 14.2 & 17.67 & 381.6 & 0.02159 & \multirow{3}{*}{1,183} & \multirow{3}{*}{0.07710} & & \\
\hline & 5 & 14.67 & 17.67 & 377.9 & 0.02136 & & & & \\
\hline & 10 & 14.73 & 17.67 & 377.2 & 0.02135 & & & 0.1289 & 0.007295 \\
\hline \multirow{4}{*}{$\begin{array}{c}\mathrm{N} 35.28 \\
\mathrm{E} 139.50 \\
\text { Nov. } 30 \\
1948\end{array}$} & 0 & 15.0 & 17.52 & 374.9 & 0.02140 & \multirow{4}{*}{1,170} & \multirow{4}{*}{0.06693} & 0.1271 & 0.007259 \\
\hline & 5 & 15.06 & 17.52 & 373.7 & 0.02133 & & & 0.1319 & 0.007532 \\
\hline & 10 & 17.52 & 17.52 & 374.3 & 0.02136 & & & 0.1317 & 0.007518 \\
\hline & 25 & 17.16 & 17.43 & 393.0 & 0.02255 & & & & \\
\hline \multirow{4}{*}{$\begin{array}{c}\mathrm{N} 35.29 \\
\mathrm{E} 139.55 \\
\text { Nov. } 30 \\
1948\end{array}$} & 0 & 13.4 & - & - & - & \multirow{8}{*}{1,180} & \multirow{8}{*}{0.06682} & & \\
\hline & 5 & 14.21 & 17.35 & 368.7 & 0.02150 & & & & \\
\hline & 10 & 15.18 & 17.66 & 374.0 & 0.02143 & & & & \\
\hline & 20 & 16.28 & 17.98 & 385.7 & 0.02146 & & & & \\
\hline \multirow{3}{*}{$\begin{array}{c}\mathrm{N} 35.20 \\
\mathrm{E} 139.47 \\
\text { Dec. } 1 \\
1948\end{array}$} & 0 & 14.4 & 17.67 & 378.2 & 0.02140 & & & & \\
\hline & 5 & 14.50 & 17.70 & 378.9 & 0.02141 & & & 0.1334 & 0.007542 \\
\hline & 10 & 15.68 & 17.97 & 384.1 & 0.02137 & & & 0.1371 & 0.007651 \\
\hline \multirow{6}{*}{$\begin{array}{c}\mathrm{N} 35.03 \\
\mathrm{E} 139.42 \\
\text { Dec. } 3 \\
1948\end{array}$} & 0 & 17.8 & 19.01 & 404.0 & 0.02125 & & & & \\
\hline & 10 & 18.27 & 19.00 & 403.8 & 0.02125 & \multirow[t]{2}{*}{1,261} & \multirow[t]{2}{*}{0.06657} & 0.1383 & 0.007281 \\
\hline & 50 & 17.82 & 19.04 & 405.5 & 0.02130 & & & 0.1368 & 0.007188 \\
\hline & 100 & 15.07 & 19.14 & 407.0 & 0.02126 & \multirow[t]{2}{*}{1,274} & \multirow[t]{2}{*}{0.06670} & 0.1409 & 0.007362 \\
\hline & 200 & 11.35 & 19.06 & 405.3 & 0.02126 & & & 0.1377 & 0.007225 \\
\hline & 400 & 7.43 & 19.01 & 410.4 & 0.02159 & 1,263 & 0.06650 & & \\
\hline \multirow{9}{*}{$\begin{array}{c}\mathrm{N} \quad 30.04 \\
\mathrm{E} 130.55 \\
\mathrm{Mar} .12 \\
1.949\end{array}$} & 0 & & 19.25 & 407.5 & 0.02142 & 1,284 & 0.06670 & & \\
\hline & 10 & & 19.22 & 405.8 & 0.02136 & 1,288 & 0.06700 & & \\
\hline & 25 & & 19.23 & 406.8 & 0.02140 & & & & \\
\hline & 50 & & 19.22 & 407.8 & 0.02147 & 1,283 & 0.06675 & & \\
\hline & 100 & & 19.21 & $4(1) 7.6$ & 0.02146 & 1,283 & 0.06684 & & \\
\hline & 150 & & 19.16 & 406.1 & 0.02145 & & & & \\
\hline & 200 & & 19.14 & 407.8 & 0.02146 & 1,275 & 0.06662 & & \\
\hline & 400 & & 19.00 & 402.1 & 0.02131 & 1,270 & 0.06685 & & \\
\hline & 500 & & 18.98 & 404.4 & 0.02146 & & & & \\
\hline
\end{tabular}

solution. The standard deviation $(\sigma)$ in this method was $0.3 \%$, when the size of samples was five.

In the first place the writer tested the modified method of S. Gripenberg6) which gave in general exact results, but occasionally by some unknown reasons 
Table 2.

\begin{tabular}{|c|c|c|c|c|c|}
\hline $\begin{array}{c}\text { Station \& } \\
\text { Depth }\end{array}$ & $\begin{array}{l}\text { Depth } \\
\text { m }\end{array}$ & $\begin{array}{l}\text { Temp. } \\
{ }^{\circ} \mathrm{C}\end{array}$ & $\begin{array}{l}\mathrm{Cl} \\
0 \%\end{array}$ & $\begin{array}{c}\text { "Ca" } \\
\mathrm{mg} / \mathrm{kg}\end{array}$ & “Ca”/Cl \\
\hline $\begin{array}{l}\text { N35.35 E139.47 } \\
\text { Depth } 6.5 \mathrm{~m}\end{array}$ & 4.5 & 20.61 & 15.64 & 319.7 & $0.02043^{*}$ \\
\hline $\begin{array}{l}\text { N35.36 E139.59 } \\
\text { Depth } 12 \mathrm{~m}\end{array}$ & 10 & 16.60 & 18.39 & 394.2 & 0.02144 \\
\hline $\begin{array}{c}\text { N35.33 E140.01 } \\
\text { Depth } 17.5 \mathrm{~m}\end{array}$ & 15 & 16.67 & 18.47 & 393.2 & 0.02128 \\
\hline $\begin{array}{l}\text { N35.31 E139.50 } \\
\text { Depth } 22 \mathrm{~m}\end{array}$ & 20 & 16.42 & 18.65 & 398.4 & 0.02136 \\
\hline $\begin{array}{l}\text { N35.29 E139.56 } \\
\text { Depth } 21 \mathrm{~m}\end{array}$ & 19 & 16.76 & 18.48 & 397.1 & 0.02148 \\
\hline $\begin{array}{c}\text { N35.26 E139.52 } \\
\text { Depth } 25 \mathrm{~m}\end{array}$ & 23 & 16.90 . & 18.56 & 398.5 & 0.02147 \\
\hline $\begin{array}{l}\text { N35.26 E139.46 } \\
\text { Depth } 34 \mathrm{~m}\end{array}$ & 30 & 16.16 & 18.79 & 400.2 & 0.02129 \\
\hline $\begin{array}{l}\text { N35.23 E139.41 } \\
\text { Depth } 46 \mathrm{~m}\end{array}$ & 40 & 15.75 & 18.84 & 405.6 & 0.021 .53 \\
\hline $\begin{array}{c}\text { N35.23 E139.43 } \\
\text { Depth } 19.5 \mathrm{~m}\end{array}$ & 17 & 16.77 & 18.72 & 400.9 & 0.02142 \\
\hline $\begin{array}{l}\text { N35.22 E139.47 } \\
\text { Depth } 20 \mathrm{~m}\end{array}$ & 18 & 17.78 & 17.88 & 382.3 & 0.02138 \\
\hline $\begin{array}{c}\text { N35.22 E139.47 } \\
\text { Depth } 14.5 \mathrm{~m}\end{array}$ & 12 & 17.64 & 18.24 & 386.4 & 0.02118 \\
\hline $\begin{array}{c}\text { N35.20 E139.47 } \\
\text { Depth } 14 \mathrm{~m}\end{array}$ & 12 & & 17.61 & 347.4 & $0.01970^{*}$ \\
\hline $\begin{array}{l}\text { N35.12 E139.46 } \\
\text { Depth } 38 \mathrm{~m}\end{array}$ & 35 & 15.18 & 18.13 & 402.1 & $0.02218^{*}$ \\
\hline
\end{tabular}

erratic results were obtained. Therefore, though somewhat laborious, the method of T.G. Thompson was adopted.

(2) Magnesium. An usual method was applied. Ammonium magnesium phosphate was reprecipitated thrice, then it was ignited at $1000^{\circ} \mathrm{C}$.

(3) Alkalinity. Using a glass electrode, ${ }^{*} 50 \mathrm{cc}$. of sample water was titrated with 0.01 normal hydrochloric acid. By a graphical solution of titration curve the end point was determined. The error accompanying this solution was $0.03 \mathrm{cc}$. which corresponds to a relative error of $0.3 \%$. E. Ruppin's ${ }^{7)}$ method was used

* This determination was made by Mr. S. Otake, to whom the writer wishes to express his hearty thanks. 
at first which proved itself being excellent as it has a sharp end point, but it gives higher results as compared with a glass electrode method since coastal water dissolves considerable amount of organic matter which disturbs the redox reaction. It might be due to that the organic matter consumes a part of the liberated iodine.

(4) Chlorinity. Using the uraninestarch solution ${ }^{8)}$ as an adsorption indicator $15 \mathrm{cc}$. of sea water was titrated with the silver nitrate solution standardized according to the direction of M. Knudsen.9)

\section{Results and Discussion.}

In the Table 1 and 2 , results are shown. According to J. L. Lyman and

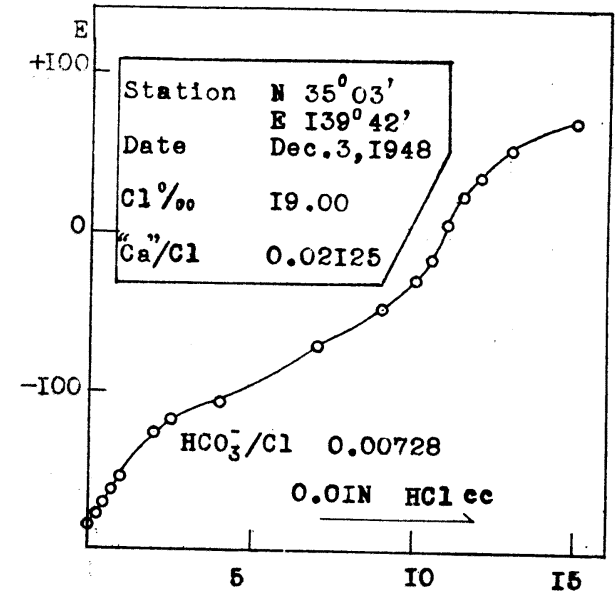

Fig. 1. Titration curve of seawater. R. H Fleming, ${ }^{10)}$ alkalinity was given in terms of the ratio of the amount of bi-carbonate per $\mathrm{kg}$ of water to chlorinity. The data given in Table 2 are the results with bottom water samples.

(1) "Calcium". As stated above, the word "Calcium" means the sum of the calcium and strontium calculated as calcium. Data obtained by the volumetric method give the amount of the "Calcium". From Table 1 the rejection limits $(\alpha=0.05)$ of the ratio were obtained as $0.02093 \sim 0.02193$. A sample marked with (*) lies beyond this limits. It is note-worthy that the sample is the only one which was collected from bottom layer. As the chemical composition of sea water is generally quite uniform and also as in other data without $\left(^{*}\right)$ in Table 1 one can see a good uniformity in the chlorinity ratio of "Calcium", it seems that the higher value might be due to an effect of the bottom. Thus the author analysed also samples of bottom water in Tokyo Bay. As is noticeable in Table 2, three samples gave the value out of the rejection limits, which might be caused by deposition, absorption, or dissolution of "Calcium", or any biological action at the bottom.

(2) On the effect of the land-water. As the chlorinity ratio of calcium of land-water is larger than that of sea water, by mixing with land water it may be expected that dilute sea water shows a higher chlorinity than usual. When an appreciable difference in the chlorinity ratio larger than the analytical error 
would be produced by mixing of land- and sea-water, we could recognize if any sorts of other chemical and physical reactions might occur or not, by comparing observed data with the calculation. But the result of calculation shows us that the effect of mixing on the chlorinity ratio is negligible as explained below.

The mean contents of calcium and chlorine of Japanese land-water are severally 10 and $9 \mathrm{mg} .11)$ per litre. On the other hand the chlorinity and chlorosity of oceanic water are assumed as 19.00 and 19.46 respectively. When the chlorosity of sea water is $X$, the next equation may be deduced: $19.46 A+0.009 B=X(A+B)$, where $A$ and $B$ denote a volume of sea-water and land-water respectively.

Then the "Calcium" content of the water may be calculated by the following equation: $(B \times 0.010+A \times 0.416) /(A+B)$. From these two equations the theoretical line was obtained, which is given in Fig. 2. From this result, it may be understood that any appreciable effect of land water, larger than the analytical error, can not be noticed in the Bay.

And there was, in fact, no significant difference between the mean value of the inner part of Tokyo Bay and that of oceanic water except water samples with a mark (*) (when examined by “Student'”-t-test, $\alpha=0.05$ ) .

(3) On the mean value of "Calcium"। Cl. According to J. L. Lyman and R. $H$. Fleming, ${ }^{10)}$ the mean value of the oceanic water is 0.0214 and that of this work is 0.0214 . As the calculated value according to D. A. Webb's proposal from the result obtained by the gravimetric method, ${ }^{1)}$ corresponds to this

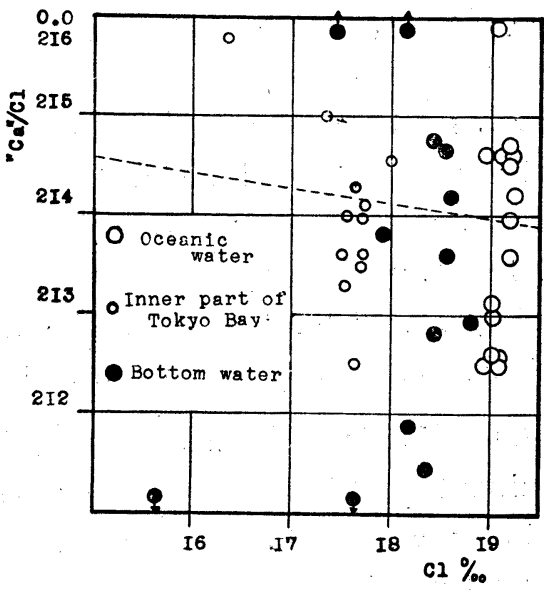

Fig. 2. The relation between "Ca" $/ \mathrm{Cl}$ and chlorinity. value, Webb's assumption may be correct.

(4) Alkalinity and "Calcium". If the change in alkalinity depends only upon that of calcium bicarbonate content,12) the molecular ratio of changes in the content of "Calcium" and bicarbonate should be $1: 2$. The theoretical line showing this relation is given in Fig. 3. The most part of observed data is distributed scatteringly in the upper part of this line. The correlation was critisised by "Student"-t-test and proved of no significance. Thus, it may be said that conversion from the alkalinity into "Calcium" is not suitable in Tokyo Bay. 
The conclusion was supported by the fact that the alkalinity changes with the consumption of nitrate or ammonium ion in sea water by plants. ${ }^{13)}$ Also, according to N. W. Rakestraw ;14) “our definition of excess base, in terms of equivalents of acid added, $A=\mathrm{HCO}_{3}^{-}+2 \mathrm{CO}_{3}^{-}+\mathrm{H}_{2} \mathrm{BO}_{3}^{-}$, is an exact definition of what we mean by excess base, not something which is merely equivalent to it'. The writer's opinion may be supported by the above definition of excess base.

(5) On the abnormal value of bottom water. From the fact that the writer recognized the abnormal value of the

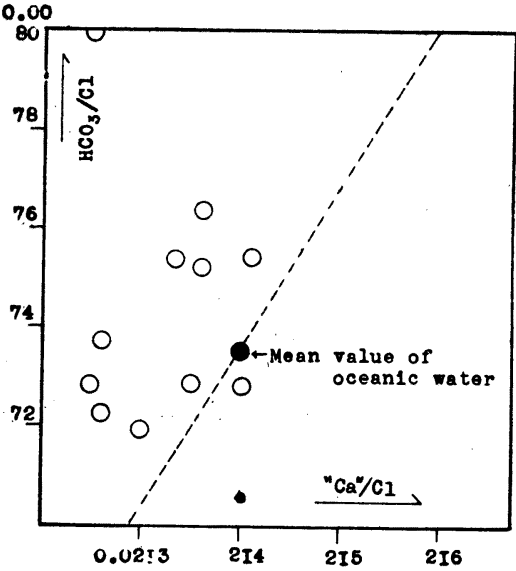

Fig. 3. The correlation of "Ca"/ $\mathrm{Cl}$ and $\mathrm{HCO}_{3} / \mathrm{Cl}$. samples stochastically as described in the previous work, and that there was no significant effect of land-water, desorption or adsorption of the "Calcium" by suspensoids transfered from the surrounding land area could not successfully explain the reason of the anormaly. It might be more reasonable that biological consumption of "Calcium" or the dissolution of the calcareous products of marine organisms would be the main factor.

(6) Alkalinity. Since the large fluctuation in the alkalinity in sea water was found in Tokyo Bay, it may be said that the fluctuation of both, the alkalinity and "Calcium", should be observed in studying on such oceanochemical problems.

(7) Magnesium. The mean value of chlorinity ratio of magnesium was 0.06681. This is slightly lower than the value, 0.06695 , formerly reported,1) but the difference is within the limit of an analytical error. The difference in the mean values between the ocean'c water and the water of the inner part of Tokyo Bay was not recognized (by "Student"-t-test, $\alpha=0.05$ ). 


\section{References}

1) Y. Matida: J. Ocean. Soc. Japan, 5 (1950), 105.

2) H. U. Sverdrup, M. W. Johnson and R. H. Fleming: "The-Oceans", (1946), 195, New York.

3) T. G. Thompson and C. C. Wright: J. Amer. Chem. Soc., 25 (1930), 975.

4) D. A. Webb: Nature, 142 (1938), 751.

5) F. W. Clark: "The Data of Geochemistry" (1924).

T. G. Thompson and R. T. Robinson: Bull. Natl. Research Council, 85 (1932), 118.

6) S. Gripenberg: J. du Conseil, 12 (3), (1937), 284.

7) E. Ruppin: Wiss. Meeres., 11 (1910).

8) Y. Miyake: J. Meteor. Soc. Japan, Ser. 2, 14 (1936), 185.

9) M. Knudsen, C. Forch and S. P. L. Soerensen: Wiss. Meeres., Kiel, N. F. 6 (1902), 123.

M. Knudsen : "Hydrographical Tables", (1901), Copenhagen.

10) J. L. Lyman and R. H. Fleming: J. Mar. Res. (1940), 134.

11) T. Hanya: International Assoc. Hydrology, Brussel Assemly, August 1951.

12) L. H. N. Cooper: J. Mar. Blol. Assoc., 20 (1934), 747.

H. Wattenberg: Ann. Hydrogr. usw., 58 (1930), 277.

13) Y. Matsue: J. Ocean. Soc. Japan, 6 (1950), 32.

14) N. W. Rakestraw: J. Mar. Res., 8 (1949), 19. 